\title{
Correction to: Ultrasound-guided supra- inguinal fascia lliaca compartment block for older adults admitted to the emergency department with hip fracture: a randomized controlled, double-blind clinical trial
}

Liang Chen ${ }^{1}$, Yang Shen ${ }^{2 *}$, Shuangmei Liu' ${ }^{1}$ Yanyan Cao ${ }^{1}$ and Zhe Zhu ${ }^{2}$

Correction to: BMC Geriatr 21, 669 (2021)

https://doi.org/10.1186/s12877-021-02646-4

After publication of this article [1], the authors reported reference [24] was missing and should have been: [24] Bouaziz H, Vial F, Jochum D, Macalou D, Heck $\mathrm{M}$, Meuret $\mathrm{P}$, et al. An evaluation of the cutaneous distribution after obturator nerve block. Anesth Analg. 2002;94(2):445-9.

The original article [1] has been updated.

\section{Author details}

1Department of Anesthesiology, Shengjing Hospital of China Medical University, Shenyang, Liaoning Province, China. ${ }^{2}$ Department of Emergency Medicine, Shengjing Hospital of China Medical University, No.36 Sanhao

Street, Heping District, Shenyang 110004, Liaoning Province, China.

Published online: 03 January 2022

\section{Reference}

1. Chen L, Shen Y, Liu S, et al. Ultrasound-guided supra-inguinal fascia lliaca compartment block for older adults admitted to the emergency department with hip fracture: a randomized controlled, doubleblind clinical trial. BMC Geriatr. 2021;21:669. https://doi.org/10.1186/ s12877-021-02646-4.

The original article can be found online at https://doi.org/10.1186/s12877-

021-02646-4.

*Correspondence: cmushy@163.com

${ }^{2}$ Department of Emergency Medicine, Shengjing Hospital

of China Medical University, No.36 Sanhao Street, Heping District,

Shenyang 110004, Liaoning Province, China

Full list of author information is available at the end of the article

(c) The Author(s) 2021. Open Access This article is licensed under a Creative Commons Attribution 4.0 International License, which permits use, sharing, adaptation, distribution and reproduction in any medium or format, as long as you give appropriate credit to the original author(s) and the source, provide a link to the Creative Commons licence, and indicate if changes were made. The images or other third party material in this article are included in the article's Creative Commons licence, unless indicated otherwise in a credit line to the material. If material is not included in the article's Creative Commons licence and your intended use is not permitted by statutory regulation or exceeds the permitted use, you will need to obtain permission directly from the copyright holder. To view a copy of this licence, visit http://creativecommons.org/licenses/by/4.0/. The Creative Commons Public Domain Dedication waiver (http://creativeco mmons.org/publicdomain/zero/1.0/) applies to the data made available in this article, unless otherwise stated in a credit line to the data. 